\title{
APPLICATION DESIGN GEOGRAPHIC INFORMATION SYSTEM OF FLOOD LOADING MAPPING IN TULUNGAGUNG REGENCY REGION
}

\author{
Mohammad Panji Romadhoni \\ Islamic University of Balitar; Jl. Majapahit No.04, Telp. (0342) 813145 \\ Program Stud Teknik Informatika, FTI Universitas Islam Balitar, Blitar \\ e-mail: paniiromadhoni78@gmail.com
}

\begin{abstract}
:
Tulungagung Regency has a history of experiencing floods, which damaged infrastructure and claimed lives in Tulungagung Regency due to the lack of facilities, knowledge and initial handling of flood disasters to be one of the contributing factors. This study uses primary data and secondary data in the form of slope data, soil type and rainfall. The results of the analysis obtained the level of flood vulnerability in the Tulungagung district area resulting in three levels of classes, namely vulnerability is very vulnerable, vulnerable, and not vulnerable. Making the system using ArcMap PHP web programming and using the MySQL database offline. To process map data used GIS tools (geographic information system), namely the spatial analysis tool of flood hazard level with a visual mapping model. The results of this study are expected to be useful in providing information on flood-prone areas in Tulungagung Regency and it is hoped that the Tulungagung Regency government and the private sector will routinely conduct disaster socialization, especially for communities in flood-prone areas.
\end{abstract}

\section{Keywords: Flood Prone, GIS, Tulungagung Regency}

\section{INTRODUCTION}

Flooding is not a new phenomenon in Indonesian society. It has become a routine annual sight in the capital city and several cities in Indonesia when the rainy season comes. The impact of flooding can vary, from the spread of disease outbreaks, property losses, to damaging infrastructure structures such as roads, buildings, and bridges. Almost all regions in Indonesia have the potential for flooding, the island which is often affected by flooding is Java. Flooding has the potential to cause aftershocks such as landslides, depending on the slope of the land through which flood water passes, the density of soil constituent particles and the speed of soil cracks. During 2013-2017 the death toll from the most flooding occurred in 2016 (Suprapto, 2011).

Topographically, Tulungagung is located at an altitude of 85 meters above sea level (asl). The northwest is a mountainous region that is part of the Wilis-Liman mountain range. The middle part is the lowlands, while the southern part is a mountain range from the Kidul Mountains. To the 
JOSAR, Vol. 1 No. 1 March, 2018; p-ISSN: 2502-8251; e-ISSN: 2503-1155

Copyrights@ Balitar Islamic University, Blitar-Indonesia

https://ejournal.unisbablitar.ac.id/index.php/josar

northwest of Tulungagung, precisely in Sendang Subdistrict, there is Mount Wilis as the highest point in Tulungagung Regency which has a height of 2,552 meters above sea level (asl). Tulungagung Regency is divided into 19 sub-districts, 257 villages, and 14 sub-districts. From the results of interviews with one of the Villages and from data collection obtained from the BPBD of Tulungagung Regency, Tulungagung Regency needed a geographic information system in flood-prone areas in Tulungagung Regency.

Geographic Information Systems according to Prahasta (2002: 55) are computer systems that are used to collect, examine, integrate, and analyze information relating to the surface of the earth. Basically, the term geographic information system is a combination of three main elements, namely system, information, and geography. Geographic Information Systems (GIS) as computer systems used to manipulate geographic data. This system is implemented with computer hardware and software which functions to acquire and verify data, compile data, store data, change and update data, manage and exchange data, manipulate data, call and present data and analyze data. (Bernhardsen 2002), ArcMap is one of the desktop software Geographic Information Systems and mapping that has been developed by ESRI.

The author builds Geographic Information System Applications Mapping Flood-Prone Locations in the Tulungagung District to find out flood-prone areas. From this application system, it is expected to be able to help the community in knowing where flood-prone areas are in Tulungagung Regency.

\section{RESEARCH METHODOLOGY}

\section{a. Time and Place of Research}

This research takes place from the first week of August 2018 to the fourth week of September 2018. The time of the study includes the preparation phase, the implementation phase until the preparation stage of 
JOSAR, Vol. 1 No. 1 March, 2018; p-ISSN: 2502-8251; e-ISSN: 2503-1155

Copyrights@ Balitar Islamic University, Blitar-Indonesia

https://ejournal.unisbablitar.ac.id/index.php/josar

the thesis. This research was conducted in Tulungagung District. Area area which is the object of research, Research Location in the Regional Disaster Management Agency (BPBD) of Tulungagung Regency which has a sub-district coverage which is the research area is Besuki, Bandung, Pakel, Campurdarat, Tanggunggunung, Kalidawir, Pucanglaban, Rejotangan, Ngunut, Sumbergempol, Boyolangu , Tulungagung, Kedungwaru, Ngantru, Karangrejo, Kauman, Gondang, Pagerwejo, Sendang, are coverage of the District in Tulungagung Regency.

\section{b. Data Collection}

Collecting data and information can be through direct observation or observation of situations and conditions that occur in the research area. Data types can be divided into:

Primary data in this study was conducted by interview method, namely through interviewing the head of the Tegalrejo Village Head in one village in Rejotangan District, Tulungagung Regency on January 22, 2018. Interviews are useful for studying and re-selecting information that has been obtained from journals, books, or papers scientific. After studying and selecting information that has been obtained, questions can be arranged about the theme concerned with this thesis to the resource person. The interview data will be used as the background of the thesis. As follows :

\begin{tabular}{|c|l|}
\hline No. & \multicolumn{1}{|c|}{ Interview } \\
\hline 1. & $\begin{array}{l}\text { Is there a history of flooding in Tegalrejo Village and what } \\
\text { are the losses? }\end{array}$ \\
\hline 2. & Has there been a flood in the village of Tegalrejo? \\
\hline 3. & Are there early warnings for floods that occur? \\
\hline 4. & $\begin{array}{l}\text { Has there been a software application that maps out } \\
\text { flood-prone areas in Tulungagung itself? }\end{array}$ \\
\hline
\end{tabular}

From table 3.2, which contains a number of questions addressed to the leaders of the Tegalrejo Village Head, one of the villages in Rejotangan District, Tulungagung Regency. Later results can be used to help design the geographic information system that will be designed.

Secondary data is supporting data that already exists so only need to find and collect the data. Secondary data in this study was obtained by visiting the office of the Regional Disaster Management Agency in 
JOSAR, Vol. 1 No. 1 March, 2018; p-ISSN: 2502-8251; e-ISSN: 2503-1155

Copyrights@ Balitar Islamic University, Blitar-Indonesia

https://ejournal.unisbablitar.ac.id/index.php/josar

Tulungagung Regency. Secondary data in the form of documents and reports covering basic aspects of data, namely:

Data on basic physical aspects include:

Type of Soil

\begin{tabular}{|l|l|c|c|c|c|c|}
\hline \multirow{2}{*}{ No } & \multirow{2}{*}{ Kecamatan } & \multicolumn{5}{|c|}{ Tekstur tanah } \\
\cline { 3 - 7 } & Halus & $\begin{array}{c}\text { Agak } \\
\text { Halus }\end{array}$ & Sedang & $\begin{array}{c}\text { Agak } \\
\text { Kasar }\end{array}$ & Kasar \\
\hline 1 & Tulungagung & - & - & $\sqrt{ }$ & - & - \\
\hline 2 & Boyolangu & - & - & $\sqrt{ }$ & - & - \\
\hline 3 & Kedungwaru & - & - & $\sqrt{ }$ & - & - \\
\hline 4 & Ngantru & $\sqrt{ }$ & - & $\sqrt{ }$ & - & - \\
\hline 5 & Kalidawir & - & - & $\sqrt{ }$ & - & - \\
\hline 6 & Pucanglaban & $\sqrt{ }$ & - & $\sqrt{ }$ & - & $\sqrt{ }$ \\
\hline 7 & Rejotangan & - & - & & - & - \\
\hline 8 & Sumbergempol & - & - & $\sqrt{ }$ & - & - \\
\hline 9 & Ngunut & - & - & $\sqrt{ }$ & - & - \\
\hline 10 & Besuki & $\sqrt{ }$ & - & $\sqrt{ }$ & - & - \\
\hline 11 & Bandung & $\sqrt{ }$ & - & $\sqrt{ }$ & - & - \\
\hline 12 & Pakel & $\sqrt{ }$ & - & $\sqrt{ }$ & - & - \\
\hline 13 & Campurdarat & $\sqrt{ }$ & - & $\sqrt{ }$ & - & - \\
\hline 14 & Tanggunggunung & - & - & $\sqrt{ }$ & - & - \\
\hline 15 & Gondang & - & - & $\sqrt{ }$ & - & - \\
\hline 16 & Kauman & - & - & $\sqrt{ }$ & - & - \\
\hline 17 & Karangrejo & - & - & $\sqrt{ }$ & - & - \\
\hline 18 & Sendang & $\sqrt{ }$ & - & $\sqrt{ }$ & - & - \\
\hline 19 & Pagerwojo & $\sqrt{ }$ & - & $\sqrt{ }$ & - & - \\
\hline
\end{tabular}

Slope

Tulungagung Regency area can be grouped into 6 (six) land slope classifications as follows:

a) Slopes between $0-2 \%$ are flat areas with an area of $46,971.24$ hectares or $40.8 \%$ in almost all sub-districts, except for Sendang, Pagerwojo and Tanggunggunung Subdistricts.

b) Slopes between $2-8 \%$ are flat to gentle areas with an area of $5,637.01$ hectares or $4.9 \%$, found in almost all districts except Tanggunggunung, Sendang, Pagerwojo, Tulungagung, Pakel, Kedungwaru, Sumbergempol, Ngunut and Ngantru. 
JOSAR, Vol. 1 No. 1 March, 2018; p-ISSN: 2502-8251; e-ISSN: 2503-1155

Copyrights@ Balitar Islamic University, Blitar-Indonesia https://ejournal.unisbablitar.ac.id/index.php/josar

c) Slopes between 8-15\% are sloping to choppy areas with an area of $8,317.46$ hectares or $7.2 \%$, found in almost all sub-districts except Tulungagung, Pakel, Kedungwaru, Ngantru, Sumbergempol and Ngunut.

d) Slopes between $15-25 \%$ are wavy to wavy areas with an area of $15,875.66$ hectares or $13.8 \%$ in Karangrejo District, Kauman, Sendang, Pagerwojo, Gondang, Bandung, Boyolangu, Campurdarat, Besuki, Tanggunggunung, Kalidawir, Pucanglaban, and Rejotangan.

e) Slopes between $25-40 \%$ are weak corrugated areas with strong waves with an area of 22,985.19 hectares or $19.98 \%$ in Gondang, Pagerwojo, Bandung, Besuki, Campurdarat, Boyolangu, Kalidawir, Pucanglaban, Gondang and Rejotangan Districts.

f) Slopes of more than $40 \%$ are strong corrugated areas with an area of $15,254.44$ hectares or $13.26 \%$ in Sendang District, Pagerwojo, Besuki, Campurdarat, Kalidawir, Gondang, Rejotangan, Tanggunggunung, Bandung, and Pucanglaban.

\section{c. System Requirement Analysis}

Hardware

Hardware specifications used to design and run geographic information system applications mapping the flood-prone areas in Tulungagung Regency as follows:

a) 1. Procesore $\quad$ : Intel(R) Core(TM) i7-5500U CPU

@ 2.40GHz 2.40 GHZ

b) RAM : $4.00 \mathrm{~GB}$

C) Hardisk : :1.00 T

Software

The software specifications used to design and run geographic information system applications mapping the flood-prone areas in Tulungagung Regency are as follows:

a) Sistem Operasi Windows 8 
JOSAR, Vol. 1 No. 1 March, 2018; p-ISSN: 2502-8251; e-ISSN: 2503-1155

Copyrights@ Balitar Islamic University, Blitar-Indonesia

https://ejournal.unisbablitar.ac.id/index.php/josar

b) XAMPP tools which consists of Apache as a WEB database viewer server and MySQL as its database

c) Sublime Text 3

d) Web Browser Mozila Firefox

\section{d. System Design}

1. Flowchart (Flowchart of System Design)

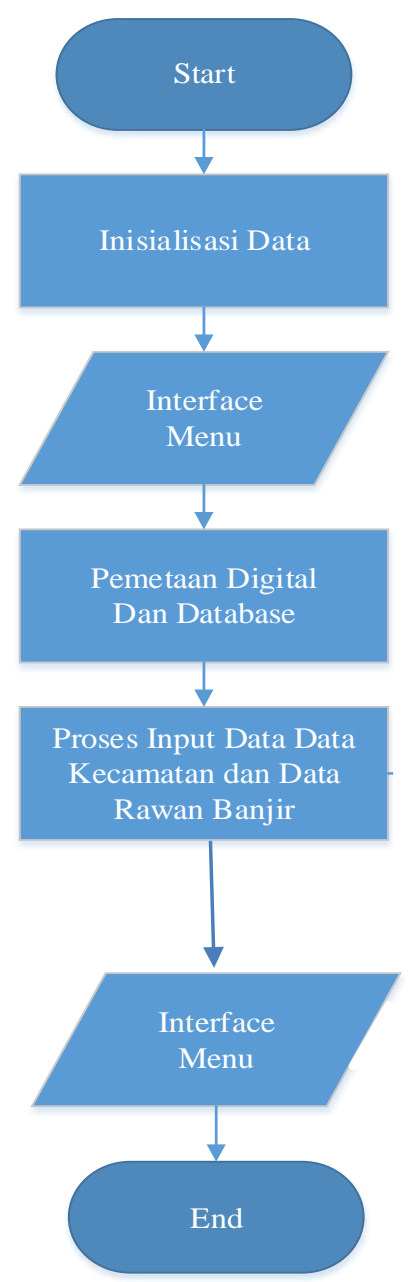

Flowchart of System Design 
JOSAR, Vol. 1 No. 1 March, 2018; p-ISSN: 2502-8251; e-ISSN: 2503-1155

Copyrights@ Balitar Islamic University, Blitar-Indonesia

https://ejournal.unisbablitar.ac.id/index.php/josar

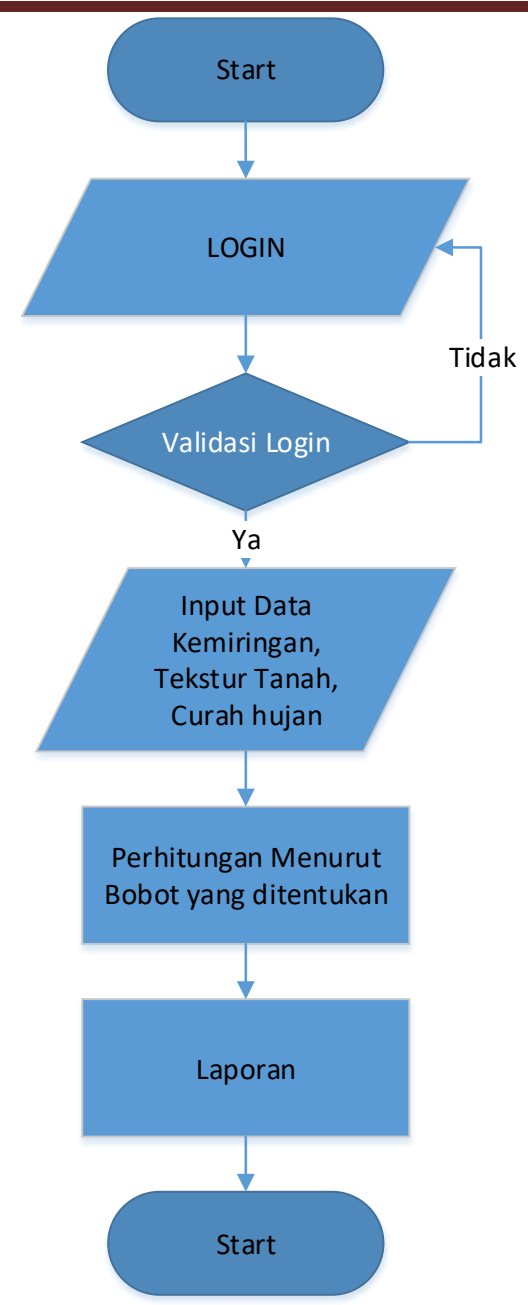

Flowchart Admin

2. Context Diagram

The description of the system is explained by the context diagram in the figure below. In this context diagram there are 2 external entities, namely admin that manages data on flood-prone areas and visitors who can request information regarding flood-prone areas. 
JOSAR, Vol. 1 No. 1 March, 2018; p-ISSN: 2502-8251; e-ISSN: 2503-1155

Copyrights@ Balitar Islamic University, Blitar-Indonesia

https://ejournal.unisbablitar.ac.id/index.php/josar

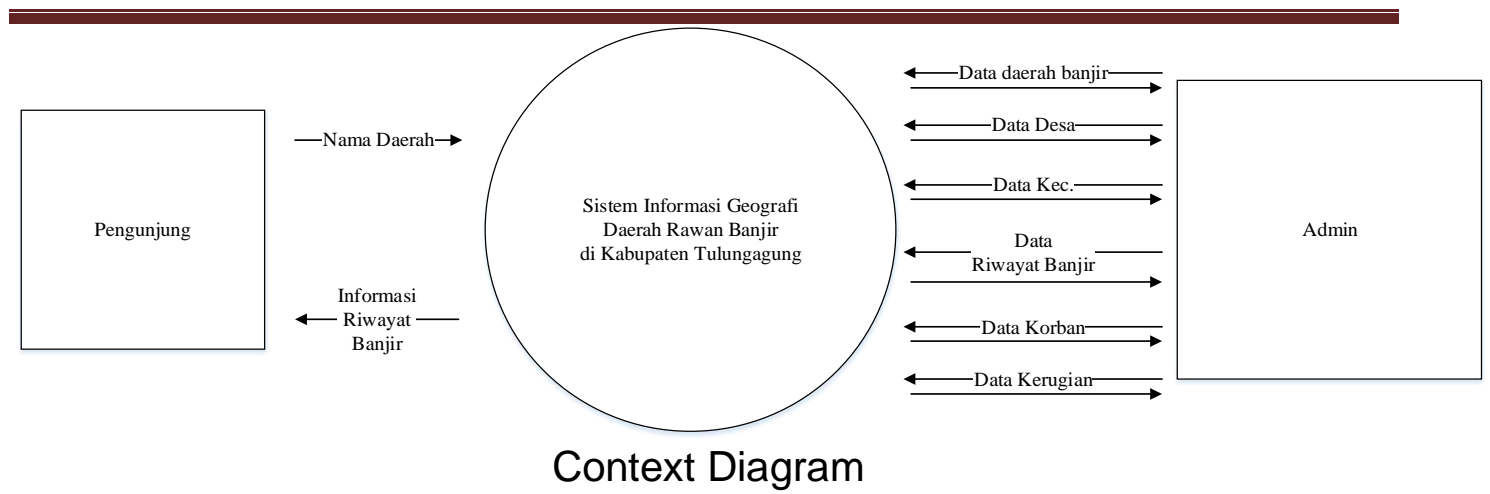

\section{Data Flow Diagram}

Data Flow Diagrams (DFD) is a graph that uses symbols to explain the course of a system by describing interconnected processes. the flow of information systems for flood-prone areas in tulungagung district can be seen in the following figure:

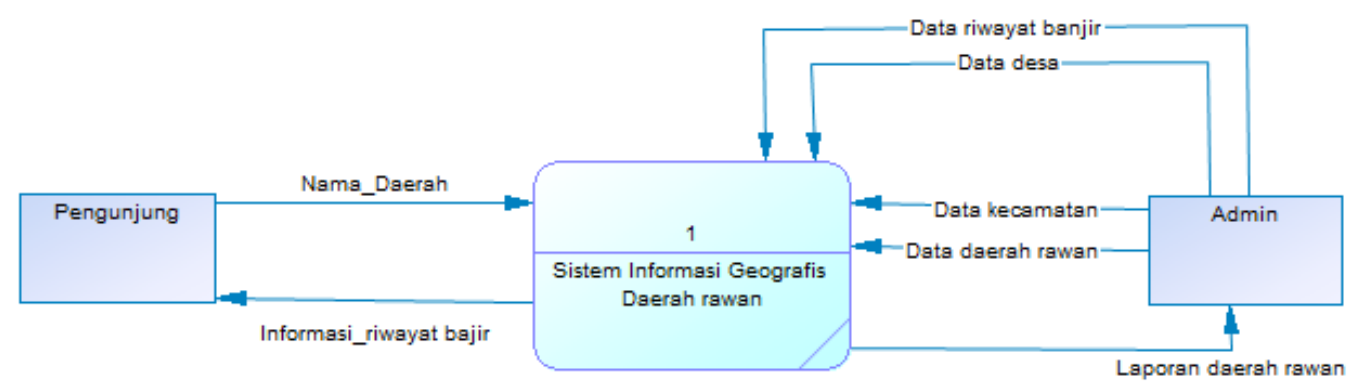

Data Flow Diagram level 0 
JOSAR, Vol. 1 No. 1 March, 2018; p-ISSN: 2502-8251; e-ISSN: 2503-1155

Copyrights@ Balitar Islamic University, Blitar-Indonesia

https://ejournal.unisbablitar.ac.id/index.php/josar

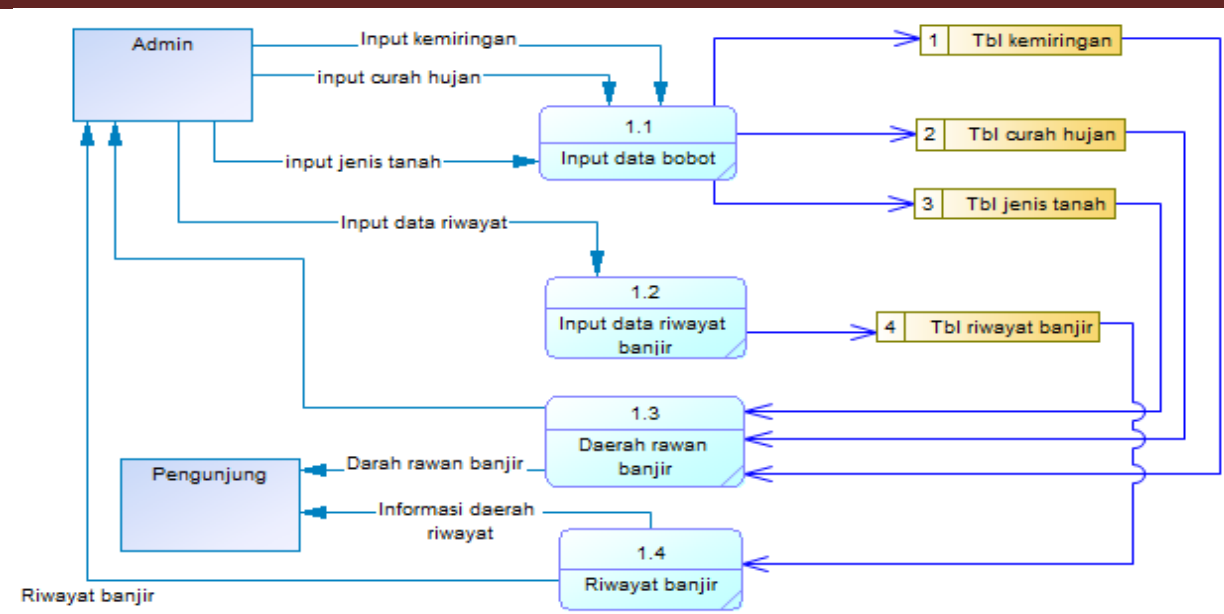

Data Flow Diagram level 1

\section{Result and Discussion}

The research succeeded in creating a system that could help map out flood-prone areas in Tulungagung Regency. Calculation of the Sturges Formula on the system is in accordance with the results of manual calculation using the conformity test as follows:

$$
\frac{(B K \times S K)+(B C \times S C)+(B J \times S J)}{\text { bobot keseluruhan }}
$$

Keterangan :

$\begin{array}{llll}\text { SK } & \text { : skor kemiringan } & \text { SJ } & \text { : skor jenis tanah } \\ \text { BK } & \text { : bobot kemiringan } & \text { SJ } & \text { : bobot jenis tanah } \\ \text { SC } & \text { : skor curah hujan } & & \\ \text { BC } & \text { : bobot curah hujan } & & \end{array}$

The results of the application of flood-prone areas were obtained from data collection from the Regional Disaster Management Agency (BPPD) of Tulungagung Regency and the following data could be generated: 
JOSAR, Vol. 1 No. 1 March, 2018; p-ISSN: 2502-8251; e-ISSN: 2503-1155

Copyrights@ Balitar Islamic University, Blitar-Indonesia

https://ejournal.unisbablitar.ac.id/index.php/josar

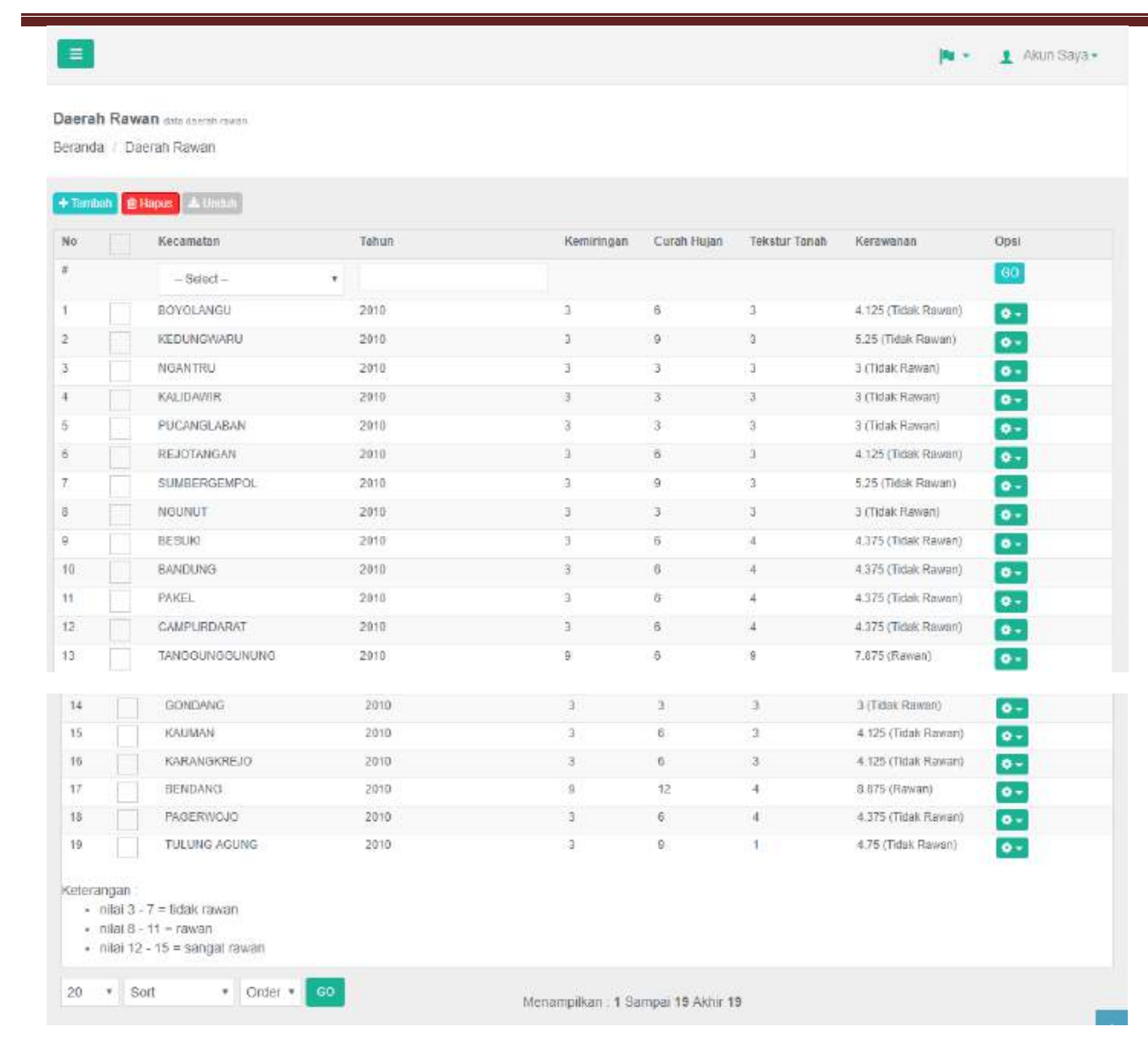

Flood-Prone Areas

After obtaining sub-district vulnerability data in Tulungagung District according to data obtained from the Regional Disaster Management Agency (BPPD) of Tulungagung Regency, the next step is mapping using ArcGISMap which will later be attached to the application page. And map display as shown below: 
JOSAR, Vol. 1 No. 1 March, 2018; p-ISSN: 2502-8251; e-ISSN: 2503-1155

Copyrights@ Balitar Islamic University, Blitar-Indonesia

https://ejournal.unisbablitar.ac.id/index.php/josar

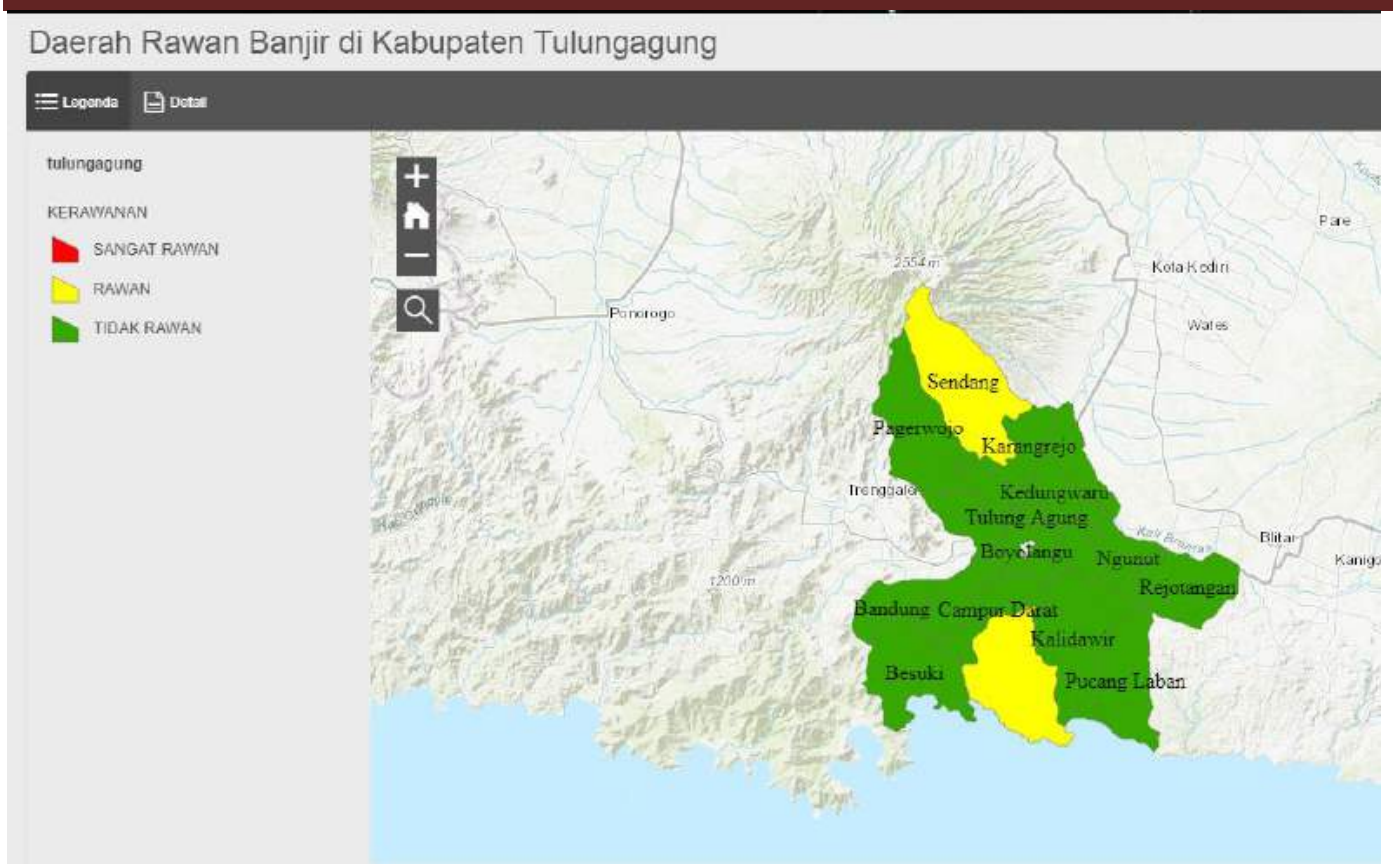

Maps of Flood-Prone Areas

In the picture of the Flood-Prone Area Map, it is known that the Sendang and Campurdarat sub-districts are categorized as flood-prone areas marked in yellow and the Pagerwojo, Karangrejo, Kedungwaru, Tulungagung, Boyolangu, Ngunut, Rejotangan, Bandung, Besuki, Kalidawir and Pucanglaban sub-districts are categorized as areas that are not flood prone is marked in green on the map.

\section{Blackbox Testing}

Testing this system aims to test whether all functions are running as expected. Test plan is needed by using the black box method found in the table as follows:

Planning of Black Box Testing

\begin{tabular}{|l|l|l|l|}
\hline No & \multicolumn{1}{|c|}{ Kelas } & \multicolumn{1}{|c|}{ Butir Uji } & \multicolumn{1}{|c|}{$\begin{array}{c}\text { Jenis } \\
\text { Pengujian }\end{array}$} \\
\hline 1. & Login & $\begin{array}{l}\text { Pengecekan admin } \\
\text { terdaftar }\end{array}$ & Black Box \\
\hline 2. & Pengisian Data & $\begin{array}{l}\text { Pengisian data } \\
\text { Pengex }\end{array}$ & Black Box \\
\hline
\end{tabular}


JOSAR, Vol. 1 No. 1 March, 2018; p-ISSN: 2502-8251; e-ISSN: 2503-1155

Copyrights@ Balitar Islamic University, Blitar-Indonesia

https://ejournal.unisbablitar.ac.id/index.php/josar

a. Login Testing

In testing the login, only the admin can log in, as follows:

Login Testing

\begin{tabular}{|c|c|c|l|c|}
\hline \multicolumn{5}{|c|}{ Data Hasil Uji ( Data Normal ) } \\
\hline No & Data Masukan & $\begin{array}{l}\text { Hasil yang } \\
\text { diharapkan }\end{array}$ & Pengamatan & Kesimpulan \\
\hline 1. & $\begin{array}{l}\text { Username : } \\
\text { admin@mail.com } \\
\text { Password : } \\
123123 \\
\text { Klik tombol login }\end{array}$ & $\begin{array}{l}\text { From } \\
\text { menampilkan } \\
\text { halaman } \\
\text { admin }\end{array}$ & $\begin{array}{l}\text { Dapat } \\
\text { masuk } \\
\text { halaman } \\
\text { admin }\end{array}$ & V \\
\hline \multicolumn{5}{|c|}{ Data Hasil Uji ( Data Salah ) } \\
\hline No & Data Masukan & $\begin{array}{l}\text { Hasil yang } \\
\text { diharapkan }\end{array}$ & Pengamatan & Kesimpulan \\
\hline 2. & $\begin{array}{l}\text { Username : aaa } \\
\text { Password : aaa } \\
\text { Klik tombol login }\end{array}$ & $\begin{array}{l}\text { Tidak dapat } \\
\text { login dan } \\
\text { tetap pada } \\
\text { halaman login }\end{array}$ & $\begin{array}{l}\text { Tetap pada } \\
\text { halaman } \\
\text { login }\end{array}$ & V \\
\hline
\end{tabular}

Based on the results of testing the admin login system successfully if it matches the username and password in the database, the user table will store the results of the system input. Description $\mathrm{V}$ is obtained if the login is successful with the percentage results as follows:

Successful presentation

Login $\%=\frac{\sum \text { Keterangan } \mathrm{V} \text { or NV }}{\sum \text { Keterangan menu or tombol }} \times 100 \%=\frac{2}{2} \times 100 \%=100 \%$

If the percentage of the success of the login system is $100 \%$

False $\%=\frac{\sum \text { Keterangan } \mathrm{V} \text { or NV }}{\sum \text { Keterangan menu or tombol }} \times 100 \%=\frac{2}{2} \times 100 \%=100 \%$

If the percentage of success of the system incorrectly entered the login username and password data is $100 \%$ 
JOSAR, Vol. 1 No. 1 March, 2018; p-ISSN: 2502-8251; e-ISSN: 2503-1155

Copyrights@ Balitar Islamic University, Blitar-Indonesia https://ejournal.unisbablitar.ac.id/index.php/josar

b. Input data Testing

In testing data only the admin can fill in as follows:

Input, Delete, Update Testing

\begin{tabular}{|c|c|c|c|c|}
\hline \multicolumn{5}{|c|}{ Data Hasil Uji ( Halaman Riwayat Banjir) } \\
\hline No & $\begin{array}{c}\text { Data } \\
\text { Masukan }\end{array}$ & $\begin{array}{l}\text { Hasil yang } \\
\text { diharapkan }\end{array}$ & Pengamatan & Kesimpulan \\
\hline 1. & $\begin{array}{l}\text { Input data } \\
\text { riwayat } \\
\text { banjir }\end{array}$ & $\begin{array}{l}\text { Data riwayat } \\
\text { banjir di inputkan } \\
\text { dan tersimpan di } \\
\text { database dan } \\
\text { dapat di } \\
\text { tampilkan di } \\
\text { halaman riwayat } \\
\text { bajir }\end{array}$ & $\begin{array}{l}\text { Data } \\
\text { berhasil di } \\
\text { inputkan }\end{array}$ & $\mathrm{V}$ \\
\hline 2. & $\begin{array}{l}\text { Delete data } \\
\text { riwayat } \\
\text { banjir }\end{array}$ & $\begin{array}{l}\text { Data riwayat } \\
\text { banjir terhapus }\end{array}$ & $\begin{array}{l}\text { Data } \\
\text { berhasil } \\
\text { dihapus }\end{array}$ & V \\
\hline 3. & $\begin{array}{l}\text { Update data } \\
\text { riwayat } \\
\text { banjir }\end{array}$ & $\begin{array}{l}\text { Data riwayat } \\
\text { banjir diubah dan } \\
\text { dapat tersimpan } \\
\text { di database }\end{array}$ & $\begin{array}{l}\text { Data } \\
\text { berhasil } \\
\text { diupdate }\end{array}$ & $\mathrm{V}$ \\
\hline \multicolumn{5}{|c|}{ Data Hasil Uji ( Halawan Daerah Rawan Banjir) } \\
\hline No & $\begin{array}{l}\text { Data } \\
\text { Masukan }\end{array}$ & $\begin{array}{l}\text { Hasil yang } \\
\text { diharapkan }\end{array}$ & Pengamatan & Kesimpulan \\
\hline 1. & $\begin{array}{l}\text { Input data } \\
\text { kerawanan }\end{array}$ & $\begin{array}{l}\text { Input data } \\
\text { kemiringan, curah } \\
\text { hujan, jenis tanah } \\
\text { dan tersimpan di } \\
\text { database }\end{array}$ & $\begin{array}{l}\text { Data } \\
\text { berhasil di } \\
\text { inputkan }\end{array}$ & V \\
\hline 2. & $\begin{array}{l}\text { Delete data } \\
\text { daerah } \\
\text { kerawanan }\end{array}$ & Data terhapus & $\begin{array}{l}\text { Data } \\
\text { berhasil } \\
\text { dihapus }\end{array}$ & V \\
\hline 3. & Update data & $\begin{array}{l}\text { Merubah data } \\
\text { daerah } \\
\text { kerawanan dan } \\
\text { tersimpan pada } \\
\text { data base }\end{array}$ & $\begin{array}{l}\text { Data } \\
\text { berhasil } \\
\text { diupdate }\end{array}$ & V \\
\hline
\end{tabular}

Based on the results of testing the successful data filling system if it matches the form in the database, the input table will store the results of 
JOSAR, Vol. 1 No. 1 March, 2018; p-ISSN: 2502-8251; e-ISSN: 2503-1155

Copyrights@ Balitar Islamic University, Blitar-Indonesia

https://ejournal.unisbablitar.ac.id/index.php/josar

the system input. Description $\mathrm{V}$ is obtained if filling success with the percentage results as follows:

Percentage of successful input, delete, update flood history data

$=\frac{\sum \text { Keterangan } \mathrm{V} \text { or } \mathrm{NV}}{\sum \text { Keterangan menu or tombol }} \times 100 \%=\frac{3}{3} \times 100 \%=100 \%$

Jika presentase keberhasilan pengisian data adalah $100 \%$

Percentage of wrong input, delete, update data weight value calculation of prone areas and flood history area in tulungagung district

$=\frac{\sum \text { Keterangan } \mathrm{V} \text { or NV }}{\sum \text { Keterangan menu or tombol }} \times 100 \%=\frac{3}{4} \times 100 \%=75 \%$

Jika presentase keberhasilan pengisian data adalah $75 \%$

After doing some testing on the main page of the system using the blackbox method, the results of the average success of each key function in this decision support system are as follows:

Blackbox Testing $=\frac{\mathrm{Uji}(\mathrm{i})+\mathrm{Uji}(\mathrm{i})+\cdots}{\text { Jumlah data yang diuji }}=\cdots$

Blackbox Testing $=\frac{100+100+100+75}{4}=94 \%$

From the results of testing blackbox it can be concluded that the system built is free of syntax errors and functionally produces results with success values of key functions of $94 \%$.

\section{III.Conclution}

Based on the design analysis, implementation and testing of the system, it can be concluded as follows:

1. The system has been successfully designed and will be continued at the stage of building the system

2. The system has been successfully built using hardware and software according to system requirements

3. The system has been successfully tested. The test results show that the system can work and can display flood-prone areas in 
JOSAR, Vol. 1 No. 1 March, 2018; p-ISSN: 2502-8251; e-ISSN: 2503-1155

Copyrights@ Balitar Islamic University, Blitar-Indonesia

https://ejournal.unisbablitar.ac.id/index.php/josar

Tulungagung Regency from rainfall data, slope and soil types according to the formula used.

\section{Reference}

Sujitno, Endang, Mesky Dianawati. 2015. Produksi panen berbagai varietas unggul baru cabai rawit (Capsicum frutescens) di lahan kering Kabupaten Garut, Jawa Barat. Pros Sem Nas Masy Biodiv Indon. Volume 1, Nomor 4: Halaman: 874-877.

Pressman, R.S. 2010. Software Engineering : a practitioner 's approach, McGraw-Hill, New York, 68.

Jogiyanto. 2005. Analisis dan Desain Sistem Informasi. Yogyakarta: Penerbit Andi.

Badan Penanggulangan Bencana Daerah Kabupaten Tulungagunng. 2010. Program Percepatan Pembangunan Sanitasi Permukiman (PPSP) POKJA Sanitasi Kabupaten Tulungagung, Tulungagung. Halaman: $1-7$.

Wirawan Rachmad. 2014. KONDISI GEOLOGI TULUNGAGUNG. Malang. Halaman : 1 - 33

Badan Perencanaan Pembangunan Daerah (BAPPEDA). 2010. Tulungagung. Halaman : $1-20$

Sutarman. 2009. Pengantar Teknologi Informasi. Jakarta: Sinar Grafika. Offset.

Hamka, Akhmad Qashlim, Syarli. 2017. SISTEM INFORMASI GEOGRAFIS KAWASAN BENCANA ALAM KABUPATEN POLEWALI MANDAR DENGAN GOOGLE MAPS, Sulawesi Barat. Jurnal IImiah IImu Komputer, Vol. 3, No

Sutrisno Muh Lukman. 2011. APLIKASI SISTEM INFORMASI GEOGRAFI UNTUK PENENTUAN TINGKAT KERENTANAN LONGSOR LAHAN DI KECAMATAN IMOGIRI KABUPATEN BANTUL, Yogyakarta.

Meriana, A. Haidar Mirza, A. Mutatkin Bakti. 2015. Perancangan Sistem Informasi Daerah Rawan Kriminalitas di Kabupaten Lahat, Palembang.

Sholahuddin Muhamad. 2015. SIG UNTUK MEMETAKAN DAERAH BANJIR DENGAN METODE SKORING DAN PEMBOBOTAN (STUDI KASUS KABUPATEN JEPARA) 
JOSAR, Vol. 1 No. 1 March, 2018; p-ISSN: 2502-8251; e-ISSN: 2503-1155

Copyrights@ Balitar Islamic University, Blitar-Indonesia https://ejournal.unisbablitar.ac.id/index.php/josar

Jeffi Annisa, Sigit Sutikno, Rinaldi. ANALISIS DAERAH RAWAN LONGSOR BERBASIS SISTEM INFORMASI GEOGRAFIS (Studi Kasus : Kabupaten Lima Puluh Kota, Sumatera Barat), Sumatera Barat. JOM FTEKNIK Volume 2 No. 2 Oktober 2015.

Alief Rusli Putra Muh. 2017. PEMETAAN KAWASAN RAWAN BANJIR BERBASIS SISTEM INFORMASI GEOGRAFIS (SIG) UNTUK MENENTUKAN TITIK DAN RUTE EVAKUASI (Studi Kasus : Kawasan Perkotaan Pangkep, Kabupaten Pangkajene dan Kepulauan) Makasar. 26 Oktober 2017

Darmawan Kurnia, Hani'ah, Suprayogi Andri. 2017. ANALISIS TINGKAT KERAWANAN BANJIR DI KABUPATEN SAMPANG MENGGUNAKAN METODE OVERLAY DENGAN SCORING BERBASIS SISTEM INFORMASI GEOGRAFIS. Semarang, Januari 2017 